\title{
COMPARATIVE EXPERIENCE OF THE EFFECTIVENESS OF FINANCING SMALL ENTERPRISES
}

\author{
Elisabeth Huszar \\ IfU GmbH Privates Institut für Umweltanalysen \\ 18 Gottfried-Schenker str., Lichtenau, Germany, 09244 \\ ehu@ifu.de
}

\begin{abstract}
The article considers existing criteria of estimation of financing subjects of small business in Germany and Russia for raising its effectiveness for Russia. We analyzed main directions and mechanisms of state support in these countries. The conducted analysis demonstrated that effectiveness indices of the activity of small enterprises in FGR essentially exceed analogous indices of the activity of enterprises of EU countries. A contribution, brought by small enterprises in the development of economy of Germany is just inestimable. For functioning and financing the activity of small enterprises in FGR, there were accepted correspondent normative acts, for example, the Trade code, one of which main statements is the following: family enterprises are encouraged in Germany by giving them the free access at markets, and there are different limitations for big enterprises. The parity of competitive flows is observed by prohibiting small business purchase for big enterprises - in Germany small enterprises are distinctly divided in dependent and independent by strict statistical accounting of these companies. The author denoted base state structures, curating programs for supporting small enterprises in Germany comparing with infrastructures, engaged for supporting subjects of small and middle business, existing in Russia. Unfortunately, program arrangements for supporting subjects of small business in RF don't include special measures for supporting priority types of activity. The support is mainly directed on certain categories of citizens: unemployed, families with many children, youth and so on.

Keywords: financing, business, small enterprise, business, subjects of small and middle business, state support, support program arrangements.
\end{abstract}

\section{Introduction}

State support of subjects of small business is an important factor in determining optimal ways of state support of small business in any country. Obviously, that development level of small business reflects the development level of the state economy in whole.

Methodological bases of the analysis of business are in works of many foreign economists $[1,2]$. Peculiarities in the development of small and middle business as a sector of market economy attracted researchers' attention repeatedly $[3,4]$, the experience of developing small business in countries with the developed market economy was analyzed in series of works $[5,6]$, at the same time there were widely studied essential measures of state support of business and offered ways of their further development $[2,7,8]$. But these works mainly considered the organizational-economic side of the activity of small and middle business. Last years a series of factors - reduction of a number of small enterprises, narrowness of the sphere of activity of small and middle enterprises - shifted accents of studying business from the analysis of the economic nature of small and middle business to studying factors that restrain its development and forms of state support. Just because of these conditions and despite a great number of studies, devoted to investigating small and middle business, development of arrangements on state support of business, this problem remains insufficiently studied.

\section{Aim of research}

The aim of this study is the analysis of the comparative experience of the effectiveness of financing small enterprises in Germany and Russia.

\section{Methods of research}

The scientific dialectical method of scientific cognition of reality, and also special methods (historical-legal - main definitions of the notions "small business", "small enterprises" were given using the historical excursion, the comparative method allowed to reveal main criteria of estimation of financing subjects of small and middle business of Germany and Russia, the statistical analysis 
of the activity of small and middle business in these countries demonstrated priority directions of the development of the economic development, the modeling method served for graphic realization of a series of structured factors, main conclusions were made using the generalization method) and other were used in the work. They all were used in mutual connection that favored the comprehensiveness, completeness and objectiveness of a scientific search, concreteness, validity and coordination of conclusions, formulated in the article.

\section{Results and discussion}

First of all it must be determined, what to understand as terms "small business", "small enterprise" within this article. Thus, in Germany the definitions "small business", "middle business" and "middle class" are not distinctly separated from each other.

Moreover, the notion "small business", inherent to Russia, is almost not used in Germany. According to classification of the Institute of national studies (Bonn, (IFM)), firms with the annual financial circulation less $10 \mathrm{mln}$ euro and the number of employed workers less 50 persons, must be related to small ones.

Now, let's consider the notion "middle business" in Germany. There are enterprises with less 500 workers and annual circulation less $50 \mathrm{mln}$ euro [1]. Small and middle firms - there are enterprises, managed by juridically independent owners, directly participating in production, completely responsible for economic risks and financing their activity usually without attracting credit means. Just they are named the middle class in Germany.

The World bank established more than 50 criteria, according to which enterprises must be related to small, in other words - to subjects of small business (SSB). Really the most claimed and most sacramental are the number of employed workers, size of the authorized capital, annual circulation, existing assets. Practically all countries prefer to limit themselves by a staff number and proceeds in an accounting period as determining criteria.

As it can be seen on presented Fig. 1, measures of relating enterprises to small ones in FGR and Russia are different, because proceeds indices for the previous calendar for relating to SSB in RF and FGR essentially differ.

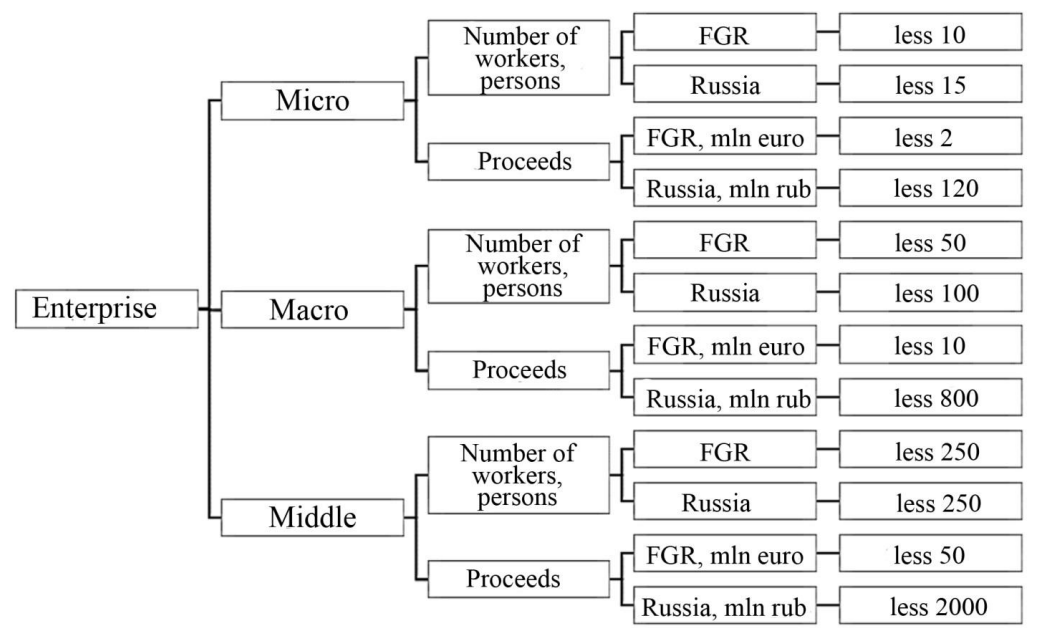

Fig. 1. Comparative criteria of gradation of enterprises by size [1]

It must be noted, that the effectiveness indices of the activity of small enterprises in FGR essentially exceed the analogous indices of the activity of enterprises of EU countries [9]. Such tendency can be partially explained by the difference of numerical values of criteria of relating enterprises to small ones in EU and Germany as to the number of workers of enterprises and proceeds [3].

A contribution, brought by small enterprises in the development of economy of Germany is just inestimable. More than $10 \mathrm{mln}$ of persons, working at these enterprises, bring their country an income more than 20 most "developed" companies of Europe. A private rule of Germany and Europe "care for small at first" has its reasons. 
For functioning and financing the activity of small enterprises in FGR, there were accepted correspondent normative acts, for example, the Trade code, one of which main statements is the following: family enterprises are encouraged in Germany by giving them the free access at markets, and there are different limitations for big enterprises. The parity of competitive flows is observed by prohibiting small business purchase for big enterprises - in Germany small enterprises are distinctly divided in dependent and independent by strict statistical accounting of these companies.

For 01 of January of 2018 3,92 mln small enterprises in the spheres of trade, industry, tourism and different services, offered to consumers were registered in Germany. It is a quintessence of the German middle class [4].

Small enterprises in Germany are supported by the following state structures:

- German house of industry and trade (DIHK);

- Federal ministry of economy and technologies (BMWI) by elaborating and realizing arrangements, directed on strengthening the entrepreneurial education and favoring small business;

- Federation of free professions (BOC);

- Fund of financing innovations (High-tech-gruenderfonds) and other.

There are several types of programs for supporting small business, one of which is financing of «Startup», which aim is in favoring the development of young business by giving loans for low interests and long-term prospect (Fig. 2) [10].

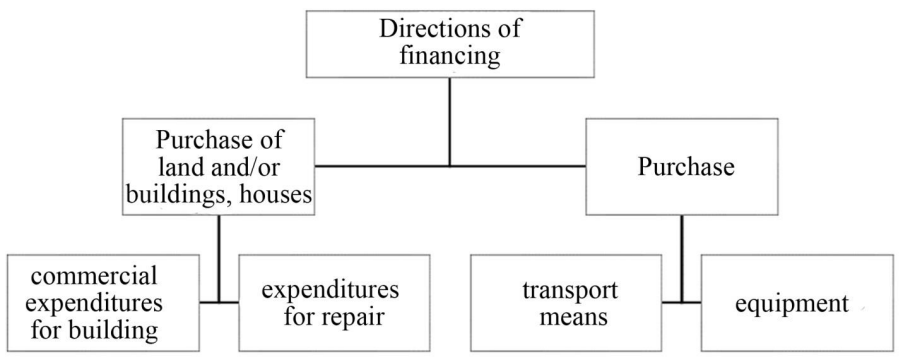

Fig. 2. Directions of financing small business

$90 \div 100 \%$ of the total need in external financing (maximal volume must not exceed 100000 euro) are financed in Germany in such a way.

This type of crediting is the most risk for commercial banks that is why there was organized the special fund, responsible for $80 \%$ of credit risks. The rate of interest is fixed for the whole term of credit (to 10 years). The guarantee of credit is not required, the bail degree is fixed individually between an applicant and bank. For getting a credit, it is necessary to create a business-plan and to present an application in the federal Ministry of economics and technologies [5].

A series of special programs, directed on help at creating a business such as ERP-Kapitalfur Grundung are elaborated in Germany (Fig. 3).

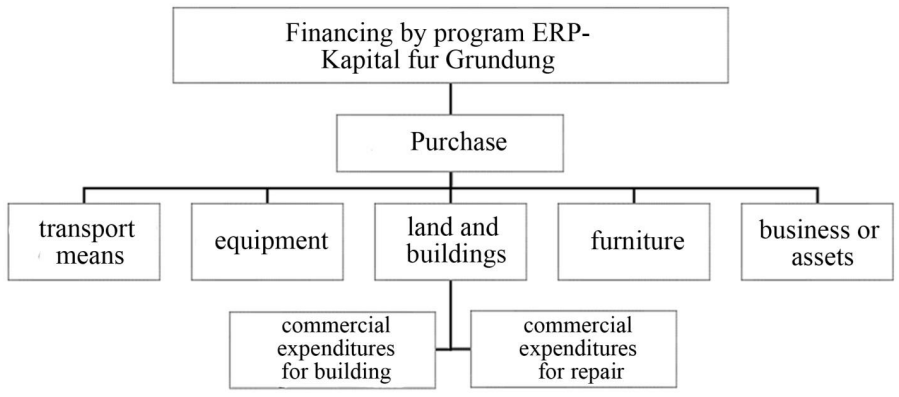

Fig. 3. Directions of financing by program ERP Kapitalfur Grundung

The maximal sum of a grant in these provided cases reaches 500000 euro. But an applicant must have $15 \%$ of the total sum as own assets for Western regions of Germany, and $10 \%$ for Eastern ones, respectively [11]. 
An owner of a grant is personally responsible for repayment of financing means that may be given for the term up to 15 years.

At the same time at the stage of business creation guarantees are given by the Association of German banks, including 17 greatest banks and 14 investment companies. The association is created for helping commercial organizations by share financing. In 2017 there were given more than 8100 of such guarantees in amount 1,7 bil euro.

The fund of financing innovations gives up to 500000 euro for 7 years for $10 \%$ interest per annum. Business-angels are also attracted as investors [2].

The great importance is also inherent so such parameter of activity as "energy effectiveness". At using resource-saving technologies by small and middle enterprises, there are given grants up to $80 \%$ of consulting services for changing the equipment, and also $30 \%$ of expenditures for necessary investments are repaid.

A series of measures is directed on studying own business start at schools and colleges. Competitions for financing the best project of students at the expanse of the Fund of business and inheritance take place. It is necessary to note, that the active participation in functioning of small and middle enterprises is realized by students - four of five ones work in this business [6].

An independent direction of financial support is a program "The improvement of economic structure of regions", investment prizes in amount from 12 to $18 \%$ of the total volume of correspondent investments are given within it, creation of each additional costly workplace is favored.

Small enterprises of Germany also use possibilities, presented by the "Program of environment improvement" [7]:

- ERP Program for purifying foul waters;

- ERP Program for purifying air;

- ERP Program for utilizing wastes;

- Program of investment guarantees for environment protection;

- Support of demonstrative arrangements in environment protection.

Summarizing, it must be noted that measures, realized by the German government within supporting small business, are effective, coordinated that is proved by official statistical data. The world practice testifies that $99 \%$ of the total number of enterprises, supported by the state - are ones of small and middle business [8]. From 2010417000 new enterprises were organized in Germany. The site of federal Ministry of economy and technologies contains more than 25000 addresses of state institutions for any questions of applicants. Near 14,6 \% of «Startup» annually are innovative [10].

The German government gives the special support to enterprises of priority directions, such as ecological condition and energy saving.

In the branch cut the activity of small enterprises of Russia and Germany is different, for example in RF the main share is trade enterprises - 39\% and $20 \%$ - the sphere of realty operations. In Germany the main share also belongs to trade $-32 \%$, but production is more developed - $21 \%$ and building - $13 \%$ (Fig. 4).

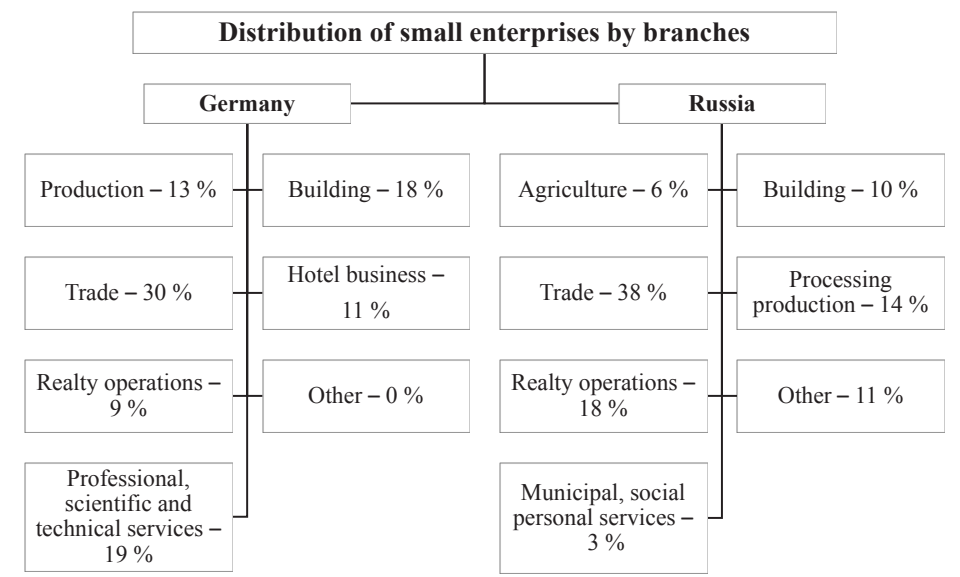

Fig. 4. Branch gradation of small enterprises in Russia and Germany (2017) 
Unfortunately, program arrangements for supporting subjects of small business in RF don't include special measures for supporting priority types of activity [12]. The support is mainly directed on certain categories of citizens: unemployed, families with many children, youth and so on.

The conducted study demonstrates that FGR government pays enough attention to the environment protection and attraction of enterprises in this sphere, but in Russia this direction is practically not developed. As it is seen from the comparative analysis of criteria of relating to subjects of small business, in Russia the index of proceeds volume for the previous calendar year for relating to subjects of small business is essentially lower. This is a very important moment, because special tax regimes are elaborated in Russia for small business (ITII, STS, patent based STS, IAT), at using which the tax load on enterprises decreases, and all taxes are replaced by one total. Enterprises, using special tax regimes, are free of paying a tax for profit and VAT.

One more negative moment is a burden, connected with paying obligatory social insurance fees as $30 \%$ of the salary fund. In Germany it is $20 \%$ of a salary, whereas at medical insurance (15.5\%, a half is paid by a worker) [10].

\section{Conclusions}

1. Based on the conducted study and further comparative analysis of the existent measures of state support, in particular -financing of small business in Germany and Russia - there is offered to realize the following arrangements for supporting small business subjects in Russia:

- to elaborate supporting programs, directed on the small business development in priority economic branches, such as building, production, municipal and house economy, education, health protection, and also in the sphere of environment protection (utilization and processing of waste, purification of foul waters and so on);

- to elaborate programs on forming entrepreneurial culture among pupils of schools and students of colleges and HEIs;

- to increase a threshold of proceeds for relating to subjects of small business.

2. Introduction of the totality of offered arrangements allows to create favorable conditions for developing small business, to form the entrepreneurial culture among the population, to decrease the tax load of business.

\section{References}

[1] World Trade Organisation (1999). The results of the Uruguay Round of Multilateral Trade Negotiations: The Legal Texts. Geneva.

[2] Cronin-Gilmore, J. (2009). Exploring marketing strategies for small businesses in the United States. Minneapolis: Northcentral University, 124.

[3] Miles, M. P., Darroch, J. (2006). Large firms, entrepreneurial marketing processes, and the cycle of competitive advantage. European Journal of Marketing, 40 (5/6), 485-501. doi: http://doi.org/ $10.1108 / 03090560610657804$

[4] Söllner, R. (2014). Die wirtschaftliche Bedeutung kleiner und mittlerer Unternehmen in Deutschland. StatistischesBundesamt. Wirtschaftund Statistik, 40-51.

[5] Hills, G. E., Hultman, C. M., Miles, M. P. (2008). The Evolution and Development of Entrepreneurial Marketing. Journal of Small Business Management, 46 (1), 99-112. doi: http://doi.org/10.1111/j.1540627x.2007.00234.x

[6] Schindehutte, M., Morris, M. H., Kocak, A. (2008). Understanding Market-Driving Behavior: The Role of Entrepreneurship. Journal of Small Business Management, 46 (1), 4-26. doi: http://doi.org/ 10.1111/j.1540-627x.2007.00228.x

[7] Maurer, H. (1994). Allgemeines Verwaltungsrecht. München.

[8] Bundeshaushaltsordnung. § 44 Zuwendungen, Verwaltung von Mitteln oder Vermögensgegenständen. Available at: http://www.gesetze-im-internet.de/bho/_ 44.html

[9] Atherton, A., Kim, J. Y., Kim, H. (2010). Who's driving take-up? An examination of patterns of small business engagement with Business Link. Environment and Planning C: Government and Policy, 28 (2), 257-275. doi: http://doi.org/10.1068/c09152

[10] Strafgesetzbuch. § 264 Subventionsbetrug. Available at: http://www.gesetze-im-internet.de/ $\mathrm{stgb} / 264 . \mathrm{html}$

[11] Federal Government Report on Research and Innovation 2010 (2010). Bonn, Berlin, 80. Available at: http://www.kooperation-international.de/fileadmin/redaktion/publication/BuFI_2010_Kurzfassung_englisch.pdf

[12] Gesetzüber die Grundsätze des Haushaltsrechts des Bundes und der Länder. Haushaltsgrundsätzegesetz. § 14 Zuwendungen. Available at: http://www.gesetze-im-internet.de/hgrg/_14.html 